\title{
Macroeconomics and Drug Use: A Review of the Literature and Hypotheses for Future Research
}

\author{
Thomas Nicholson ${ }^{1}$, David F. Duncan ${ }^{2,3}$, Gregory Ellis-Griffith ${ }^{1, *}$ and Akihiko Michimi ${ }^{4,5}$ \\ ${ }^{1}$ Western Kentucky University, Bowling Green, KY 42101, USA \\ ${ }^{2}$ Duncan \& Associates, Bowling Green, KY 42101, USA \\ ${ }^{3}$ Brown University, Providence, RI 02912, USA \\ ${ }^{4}$ Emmanuel College, Boston, MA 02115, USA \\ ${ }^{5}$ University of Connecticut, Storrs, CT 06269, USA
}

\begin{abstract}
Despite more than a century of drug prohibition, problems of addiction and drug abuse continue to be major global public health and criminal justice concerns (United Nations Office on Drugs and Crime, 2015). It has long been obvious that many of these problems are entwined with other economic and social issues. The editors of The Economist, in reporting evidence of a decline in drug use in the UK, speculated on the impact of the concurrent economic slowdown and commented that, "few academics have studied the link between drug use and macroeconomic performance, and what work exists is inconclusive" (Drug use and abuse: The fire next time, 2011). The goal of this paper will be to examine the work that exists on this topic and to propose a set of hypotheses to be tested in future studies.
\end{abstract}

Keywords: Economics, recession, unemployment, drug use, drug abuse.

\section{INTRODUCTION}

Despite more than a century of drug prohibition, problems of addiction and drug abuse continue to be major global public health and criminal justice concerns (United Nations Office on Drugs and Crime, 2015). It has long been obvious that many of these problems are entwined with other economic and social issues. The recent worldwide economic crisis has raised the issue of the potential impact of macroeconomics on drug use and abuse.

Karanikolos, et al. (2013), Quaglio, et al. (2013) and Maddock, McGurk, and Thomas (2015) are among policy analysts raising the question of how the austerity many nations have adopted in response to the recession is affecting public health services, including drug abuse prevention and treatment activities. All find reason to fear that austerity budgets for drug abuse programming will have negative effects on the wellbeing of the public.

The European Monitoring Centre for Drugs and Drug Addiction (EMCDDA) (2010) expressed the concern that, "as Europe enters a period of economic austerity, with rising levels of youth unemployment, there are fears that this may be accompanied by an increase in problematic forms of drug use." As the

*Address correspondence to this author at the Department of Public Health, Western Kentucky University, 1906 College Heights Boulevard, Bowling Green, KY 42101, USA; Tel: 270-745-3076; Fax: 270-745-4437;

E-mail: gregory.ellis-griffith@wku.edu
EMCDDA annual report points out such an increase spawned by the recession would be consistent with the observation that economically "depressed and marginalized communities have always been at elevated risk of experiencing drug problems"(p. 13).

In this regard, the editors of The Economist (2011), in reporting evidence of a decline in drug use in the UK, speculated on the impact of the concurrent economic slowdown and commented that, "few academics have studied the link between drug use and macroeconomic performance, and what work exists is inconclusive".

A recent literature review by DeGoeij, et al. (2015) found 16 studies that reported evidence for two behavioral mechanisms by which economic crises could influence alcohol consumption and alcoholrelated health problems in a population. The first mechanism suggested is that psychological distress triggered by unemployment and income reductions can increase drinking problems. The second mechanism suggested is that less money will be spent on alcoholic beverages due to tighter budget constraints. How the opposite pressures of these two mechanisms balance out in their effect on levels of drug use and drug abuse in populations is an important question that has not been answered.

Dom et al. (2016) conducted a review of studies of drug use in the European Union countries during the 2008 economic crisis. They found a decrease in alcohol consumption and cigarette smoking, which they 
attributed to reductions in disposable income. In contrast, the limited number of studies on prevalence of use of illegal drugs showed increases in use during the economic crisis.

The goal of this paper will be to examine the published research that exists on the topic of the associations between macroeconomic change and the use and abuse of drugs. Consistent with the mechanisms identified by DeGoeij, et al. (2015), we will examine whether the literature shows differential effects on drug use and problematic drug abuse. We will also, consistent with Dom et al. (2016), examine the published research for evidence of differential effects on different categories of drugs, such as between effects on alcohol use and on use of illicit drugs.

In addition, we will propose a set of hypotheses that we believe should be tested in future studies along with data sources and analytic strategies that would be useful in conducting such studies.

\section{THE STATE OF THE LITERATURE}

A vast body of research exists that shows associations between socioeconomic class and various health status indicators (Feinstein, 1993; Yen \& Syme, 1999; Lantz \& Pritchard, 2010). There is much less evidence, however, indicating whether changing macroeconomic conditions are associated with changes in the prevalence of drug abuse or other health problems.

\section{Macroeconomics and Community Health}

Mortality rates are one community health status indicator for which there are studies of macroeconomic effects. Early on, the work of Brenner (1971, 1979, 1984, 2005) and his associates dominated the field. Brenner (1979) noted that, "The long-term upward trend in real per capita incomes is associated with better health, but the smoothed curve disguises cyclic fluctuations, recessions followed by periods of rapid economic growth, which may be stressful to certain groups in the workforce and, by extension, to their families". Applying a time-series model with lagged effects, they developed an economic change model of mortality and concluded that economic downturns were associated with increasing mortality. While Brenner's findings were widely reported and were consistent with what many economists and public health professionals considered to be common sense conclusions, the methodology was criticized on statistical grounds by a number of economists and statisticians (e.g., Gravelle, Hutchinson, and Stern, 1981; Wagstaff, 1985; Søgaard, 1992). Criticisms have included the choice of lag lengths, the choice of covariates, the hypothesized pattern of lag coefficients, shifting specifications over time, and the implausibility of the finding of strongest effects for infants and the elderly, groups for which macroeconomic forces would not seem likely to have their greatest effects. Analyses that corrected for these problems have failed to replicate Brenner's findings (Forbes \& McGregor, 1984; McAvinchey, 1988; Joyce \& Moan, 1993; Wagstaff, 1985).

In contrast to Brenner's conclusions, when Ruhm (2000) examined state-level vital statistics data he found that mortality increases during economic upturns and declines during recessions. Ruhm found that for every $1 \%$ increase in the state unemployment rate the total mortality rate could be expected to decrease by $0.5 \%$. Increases in unemployment were predictive of particularly large reductions in traffic deaths and other accidental fatalities. Unemployment rate increases also seemed to be predictive of decreases in deaths due to heart disease, influenza/pneumonia, and infant mortality. Cancer mortality was found to be unrelated to unemployment rates. Suicide was the only major cause of death that was found to increase when unemployment increased. These findings were replicated in an analysis of data on twenty-three European nations (Gerdtham \& Ruhm, 2006). For these nations every $1 \%$ decline in unemployment predicted that total mortality would increase $0.4 \%$, liver disease deaths $1.8 \%$, motor vehicle deaths $2.1 \%$, and other accidents $0.8 \%$.

In an analysis of US vital statistics and economic data, Tapia Granados (2005) found that during the $20^{\text {th }}$ Century the long-term trend toward declining total mortality and mortality for specific groups, ages and causes accelerated during recessions and was reduced or even reversed during periods of economic expansion. The sole exception was that of suicides, which increased during recessions.

In a subsequent study, Tapia Granados (2008) found that economic growth was positively associated with improving population health in Sweden throughout the 19th century. However, the relationship became weaker as the century continued and was completely reversed in the second half of the 20th century. In the second half of the century economic growth began to negatively affect health indicators. Models using 
inflation and unemployment as economic indicators revealed similar results.

In attempting to answer the question, "what will the current economic crisis mean for the health of the people of Northern Ireland?," Stuckler, et al. (2009a) reviewed the experience of three major economic crises in the $20^{\text {th }}$ century: the Great Depression (1929), the Post-communist Depression (early 1990s) and the East Asian financial crisis (late 1990s). They concluded that the historical evidence suggested that health is at risk in times of rapid economic change - both in booms and busts. Further, they noted that history also showed that the impact of economic downturns on mortality was exacerbated where people have easy access to the means to harm themselves and was ameliorated by strong social cohesion and social protection systems. On this basis, they predicted that the health of the people of Northern Ireland might escape relatively unscathed in the short term.

Stuckler (2009b) used multivariate regression, correcting for population ageing, past mortality rates, past employment trends, and country-specific differences in health-care infrastructure, to examine associations between changes in unemployment rates and mortality for 26 European Union countries between 1970 and 2007. They found no consistent evidence for an increase in all-cause mortality when unemployment increased. Increases in unemployment were associated with significant short-term increases in premature deaths from intentional violence and in reduced traffic fatalities.

\section{Microeconomics and Drug Use/Abuse}

A number of studies have examined the impact of unemployment on individuals' use of alcohol. Crawford, et al. (1987) found in a general population survey in the United Kingdom that unemployment was associated with heavier alcohol use. Ettner (1997) examined data from the US 1988 National Health Interview Survey and found that non-employment significantly reduces both average daily alcohol consumption and number of symptoms related to alcohol dependence. Ettner suggested that this was probably due to an income effect. In an analysis limited to cases of involuntary unemployment he found a mixed effect whereby job loss increased the consumption of alcohol in the total sample but reduced dependence symptoms among individual respondents.

A series of studies have examined this issue at the individual level in Finland. Mustonen, Paakannen, and
Simpura (1994) found an association between unemployment and heavier alcohol use in Finland. Lahelma, Kangas, and Manderbacka (1995), on the other hand, found that neither frequency of drinking nor of intoxication was associated with employment status for men or women. In contrast, they found that the frequency of health problems due to drinking was associated in a statistically significant way with unemployment among men but not among women. Luoto, Poikolanen, and Uutela (1998) found that before and during the recession of the 1990s unemployment was weakly associated with the upper consumption level ( 8 or more drinks per week for men, five or more for women) among poorly educated, single unemployed men and highly educated, single unemployed women.

Bor, Basu, Coutts, McKee, and Stuckler (2013) compared surveys of alcohol use in the overall U.S. adult population conducted prior to (2006/2007) and during (2008/2009) the Great Recession. That study found a small but significant decrease in the proportion of drinkers from prerecession (52\%) to recession $(51.6 \%)$. This decrease appeared to be due to an increase in the number of individuals who had lost the financial resources, perhaps due to job loss, to purchase alcohol. Among drinkers, however, number of drinking days per month and number of monthly binge drinking episodes increased significantly from prerecession to recession.

Frone (2015) similarly compared data from two surveys of U.S. workers conducted prior to (20022003) and after (2008-2011) the Great Recession. The results revealed a higher proportion of drinkers among middle-aged employees, but not among young employees, after the recession. Gender and race did not moderate the relation of the recession to drinker status. Among drinkers, the recession was not related to frequency or quantity of alcohol use, but was positively related to the frequency of heavy drinking and intoxication. Among drinkers, gender, race, and age did not moderate the relation of the recession to alcohol use.

\section{Macroeconomics and Mental Health}

Since abuse of and addiction to alcohol and other drugs falls within the rubric of mental disorders, studies of macroeconomic factors and mental disorders are relevant to our study. The seminal study on this subject is that of Faris and Dunham (1939), which studied the place of residence of 35,000 Chicago residents who 
had received psychiatric treatment between 1922 and 1931 at area mental hospitals. Faris and Dunham found that rates of schizophrenia were highly associated with the socioeconomic status of the neighborhoods in which persons lived. Hollingshead and Redlich (1958) found the same thing in New Haven, Connecticut. Social researchers theorized that this association was due to people living in poverty being isolated from the normal social contacts necessary to develop a mentally healthy personality. This was commonly stated as "the slums are the breeding ground of mental illness" and was known as the "breeder hypothesis" (Duncan, 1988, p. 97).

More than two decades later a study of the prevalence of schizophrenia in Detroit found no significant difference when the economic status of the person's parents was examined rather than their own current economic status (Dunham, 1965 and Dunham, Phillips, \& Srinivasan, 1966). Based on these results, Dunham theorized that schizophrenics became poor because of their illness rather than ill because of their poverty. This became known as the "drift hypothesis" because it suggested that schizophrenics drifted into the slums because of their inability to function successfully in the workplace.

Brenner (1967) examined the association between mental hospital admissions and unemployment in New York State over the period 1910 to 1960 . He found a strong inverse relationship between mental hospital admissions and the employment index. The data revealed, however, that subgroups among the hospitalized population exhibited grossly different patterns of reaction to economic changes. In Brenner's words, "For reasons not yet well understood, risk of exposure to economic stress appears to vary with diagnostic category of illness and socioeconomic status."

Brenner (1975) also looked at the relationship between economics and alcohol use. He found that the long term trend and shorter term fluctuations in the state of the economy were both related to alcohol consumption, but in different ways. The long term trend of increasing per capita personal income was positively correlated to per capita alcohol consumption. In short term fluctuations, however, there was an inverse relationship.

In his state-level analysis Ruhm (1995) found a procyclic (positive) association between state economic conditions and alcohol consumption. Freeman (1999), using an extended panel, confirmed Ruhm's finding of a pro-cyclical pattern in alcohol consumption.

Makela (1999) studied the alcohol-related mortality rates in Finland during a period of economic boom followed by recession. The analysis showed that alcohol-related mortality increased during the economic boom and decreased slightly during the recession. Persons of low socioeconomic status tended to have a greater increase during the economic boom and a smaller decrease during the recession.

Freeman (2001) examined beer sales in the US in relation to economic upturns and downturns and concluded that, "beer consumption is relatively impervious to the vicissitudes of economic cycles". Kruger and Svensson (2010) studied alcohol sales in Sweden and found that they increased during shortterm economic upturns. Dee (2001) conducted an analysis of data from the Behavioral Risk Factor Surveillance System that showed the prevalence of binge drinking to be strongly countercyclical.

As we previously noted from an editorial in The Economist (2011), few studies have examined the prevalence of drug use in relation to economics. Examining government data from five countries, Smart and Murray (1983) found that increases in officially recorded measures of drug abuse were related to improvements in economic conditions. Extending their analysis to 152 countries, they found that measures of public health status rather than economic indicators were the best predictors of level of drug abuse. Smart and Murray (1985) concluded that the data did not support a hypothesis that drug abuse was associated with higher levels of socioeconomic development.

Catalano, Rook, and Dooley (1986) examined data describing approximately 3,850 principal wage earners interviewed over a four-year period in the Los AngelesLong Beach metropolitan area. Results suggest that job insecurity due to high levels of unemployment increases the likelihood of drug abusers considering seeking help and of them actually seeking help. The effect withstands controlling for most known personlevel predictors of help-seeking including symptoms of psychological distress and social support.

Gascon and Spiller (2009) conducted a trend study to determine if there was a relationship between counties unemployment rates and rates of opiate exposure in Kentucky. The time period analyzed was from 2000 through 2005. Data were obtained from the 
US Census Bureau, US Department of Labor, and the Kentucky Regional Poison Center. Three of the six years $(2000,2002,2003)$ showed a significant positive correlation between higher unemployment rate and higher rate of opiate exposure. The largest negative correlation was noted in 2004, which was also the period wherein the unemployment rate decreased statewide. Correlations for the remaining two years (2001 and 2005) failed to reach statistical significance.

Positive associations between economic growth and alcohol and other drug use and negative (countercyclic) associations between unemployment rates and such use has usually been attributed to greater ability to afford drugs in times of prosperity. A number of person level studies support this interpretation. Bellis, et al. (2007), for instance, found that British adolescents with more spending money were more likely to drink frequently, to binge drink, and to drink in public. Martin, et al. (2009) similarly found that college students in the US with lower levels of spending money had lower levels of drinking and getting drunk. Humensky (2010) found that higher parental income is associated with higher rates of binge drinking and marijuana use among their children.

\section{PROPOSED HYPOTHESES}

Based on this examination of the extant literature, we have formulated six hypotheses that we believe would be worth testing regarding the relationship between the state of the economy and the non-medical use and abuse of alcohol and other drugs. These six hypotheses are not proposed as exhaustive of the possible topics worth study but simply as a good starting point in studying this largely unexamined subject.

Hypothesis One: In times of low unemployment (< $5 \%)$, non-medical drug use will increase. Around 69\% of the US gross domestic product is private consumer spending (The Economist, 2015, p.236). While spending in the illegal drug trade is not assessed in the GDP because it is a black market, it seems likely that the impact of the larger economy on spending behavior in this market is similar. It can be argued that drug consumption behaves in a pro-cyclical fashion. In times of lower unemployment $(<7 \%)$, individuals have access to more money and have the opportunity to demand more goods including illegal drugs.

Hypothesis Two: Alternatively, it can be theorized that non-medical drug use behaves in a countercyclical manner, that is, that in times of higher unemployment (> 7\%), drug consumption will increase. As unemployment increases, more individuals are out of work and have less access to money to demand normal goods/services. Along lines pioneered by Brenner (1971, 1973), one can hypothesize that high unemployment creates stresses for individuals that may motivate them to take drugs for relief or escape.

Hypothesis Three: The price environment, as measured by the Consumer Price Index (CPI) will have a differential effect on the moderate use of illegal drugs among low income and middle income persons compared to high income persons. It is conceivable that spending on drugs is affected by the amount of disposable income people have. If such is the case, then we would expect those with greater reserves of disposable income to have their spending on drugs affected to a lesser extent than those with more tenuous incomes.

Hypothesis Four: The price environment (as measured by $\mathrm{CPI}$ ) will have a differential effect on the moderate use of alcohol and other legal drugs among low income and middle income persons compared to high income persons. It may be that the portion of their income that wealthy individuals spend on alcohol and other drugs is so small compared to their total disposable income that fluctuations in the economy have little or no effect on their drug expenditures. This might insulate their drug spending from economic impacts that may affect those with smaller incomes.

Hypothesis Five: The association between the price environment (as measured by $\mathrm{CPI}$ ) and moderate drug use differs significantly from their impact on drug abuse. For moderate drug users spending on drugs may be thought of as discretionary spending from the money left after paying for necessities. It can thus be seen as akin to entertainment, dining out, or other such expenditures. For the addicted drug abuser, spending on drugs is one of the necessary expenditures of daily life and thus less open to being reduced in response to any decline in income or worries about the economy. Furthermore, it is possible that personal stressors related to an economic downturn may make vulnerable individuals more likely to begin or increase abusive drug taking.

Hypothesis Six: The association between the price environment (as measured by $\mathrm{CPI}$ ) and moderate use of alcohol, a legal drug, will differ significantly in strength from that with use of illegal drugs. In most 
places in America alcohol is sold in a legal market. The currently illegal drugs, on the other hand, are only available in a black market in most places in America. This could have a material impact on the way in which economic fluctuations might affect spending on alcohol versus illegal drugs. For instance, the more diverse market in alcohol, with clearer differences in price and in quality, may make alcohol expenditures more fungible. It can be much easier for the alcohol purchaser to switch to a cheaper brand than it would be for the purchaser of illegal drugs to do so in a black market where the choices available may be far more limited.

\section{MEASUREMENT}

\section{Drug Use Measures}

There are a number of potential data sources on drug taking (both use and abuse) that could be utilized in a study of the impact of the economy on drug consumption. The most extensive and sophisticated of these appear to be surveys conducted in the United States. These surveys could provide the drugs data for a study of the US economy and drug taking. Most appropriate are the National Survey on Drug Use and Health, the Monitoring the Future survey, and the Youth Risk Behavior Survey.

The National Survey on Drug Use and Health (NSDUH), originally called the National Household Survey on Drug Abuse (NHSDA), is an annual nationwide survey of a representative sample of persons aged 12 or older at their places of residence, which has been conducted since 1971. Data from the NSDUH provide national and state-level estimates on the use of tobacco products, alcohol, illicit drugs (including non-medical use of prescription drugs) and mental health in the United States. The NSDUH serves as the U. S. Government's primary source of information on the nature and extent of substance use and abuse in the population (Substance Abuse and Mental Health Services Administration, 2012).

Monitoring the Future is a research program exploring changes in important values, behaviors, and lifestyle orientations of contemporary American youth through three substudies: (1) an annual survey of high school seniors that was initiated in 1975; (2) ongoing panel studies of representative samples from each graduating class that have been conducted by mail since 1976; and (3) annual surveys of 8th and 10th graders that were initiated in 1991. The surveys are conducted using a multistage area probability sample design involving three selection stages: (1) geographic areas or primary sampling units (PSUs), (2) schools (or linked groups of schools) within PSUs, and (3) students within sampled schools. Students in each grade are randomly assigned to complete one of four questionnaires, each with a different subset of topical questions but containing a set of "core" questions on demographics and drug use. The survey annually samples an average of about 400 public and private schools and about 50,000 students. (Bachman, Johnston, O'Malley, \& Schulenberg, 2006; Johnston, O'Malley, Bachman, \& Schulenberg, 2013)

The U.S. Centers for Disease Control developed the Youth Risk Behavior Surveillance System (YRBSS) to monitor six categories of priority health-risk behaviors among youth nationwide. Conducted biennially since 1990, the Youth Risk Behavior Survey (YRBS) measures behaviors related to intentional and unintentional injury, sexual activity, diet, physical activity, tobacco use, and alcohol and other drug use among representative samples of students in grades 9 through 12. The YRBSS includes a national schoolbased survey conducted by CDC as well as state, territorial, and local school-based surveys conducted by education and health agencies (Brener, Kann, Shanklin, Kinchen, Eaton, Hawkins, \& Flint, 2013).

Most of the above sources will provide data on levels of drug consumption in general but researchers may want to examine the relationship between economic change and drug abuse. The National Survey on Drug Use and Health derives estimates for levels of drug dependence and abuse in the population based on a set of questions derived from diagnostic criteria from the American Psychiatric Association (1994). A researcher who wishes to examine associations between economic indicators and drug abuse might find the National Survey of Substance Abuse Treatment Services or the Treatment Episode Data Set useful.

The National Survey of Substance Abuse Treatment Services (N-SSATS) is an annual census of all drug and alcohol abuse treatment facilities in the United States. N-SSATS is designed to collect data on the location, characteristics, and utilization of services at public and private alcohol and drug use treatment facilities throughout the 50 States, the District of Columbia, and other U.S. jurisdictions. This includes a patient census for each facility.

The Treatment Episode Data Set (TEDS) is a compilation of data detailing the demographic and 
substance use characteristics of admissions to and discharges from substance use treatment. TEDS is part of the Behavioral Health Services Information System (BHSIS), formerly known as the Drug and Alcohol Services Information System (DASIS), a cooperative program among the Substance Abuse and Mental Health Services Administration and state substance abuse agencies to collect data on substance use treatment services.

Non-US data sources tend to be of more recent origin, providing less data for historical comparisons. A number do exist, however, and they might prove useful for researchers wishing to take a European or world approach to the subject. National data also will be available for many individual countries, which some researchers may choose to utilize.

The European Monitoring Centre for Drugs and Drug Addiction (EMCDDA) is one of the European Union's decentralized agencies. Inaugurated in Lisbon in 1995, it has been designated by the EU as the reference point on drugs and drug addiction information in Europe. EMCDDA initiated an annual European Drug Report in 2014 (Mounteney \& Griffiths, 2014). Previously they had published an Annual Report on the State of the Drugs Problem in the European Union from 1995 through 2012.

The European School Survey Project on Alcohol and Other Drugs (ESPAD) is a collaborative effort of independent research teams in more than forty European countries and the largest cross-national research project on adolescent substance use in the world (Ritson, 2003). The overall aim of the project is to repeatedly collect comparable data on substance use among 15-16 year old students in as many European countries as possible. Surveys have been conducted since 1995, with 39 countries participating since 2011.

The World Drug Report, produced annually by the United Nations Office On Drugs and Crime (UNODC), presents an overview of developments in the world's illicit drug markets, focusing on the production, trafficking and consumption of the main types of illicit drugs, along with the related health consequences of those drugs. The report currently compiles data from national sources in ninety-eight nations.

The Global Drug Survey is an exchange hub for surveys conducted in many nations. A new entry into the field, it may become a useful source for prospective data but has little or no data for retrospective analysis.

\section{Economic Measures}

One of the most important measures of the economic status of the nation is the Consumer Price Index (CPI). The index is based upon a national recurring survey that is conducted by the U.S. Department of Labor's Bureau of Labor Statistics (BLS), which is part of the U.S. Department of Labor (Bureau of Labor Statistics, 2015). CPI seeks to identify the level of real spending by consumers on a market basket of represented goods/services (Casler, 1992; Bureau of Labor Statistics, 2015). Examples of market basket items include but are not limited to food, medical care, professional services, shelter, clothing, transportation, and electronics (Bureau of Labor Statistics, 2015). The index is calculated by analyzing the price changes of these basket items from year to year. The market basket items are then weighted to reflect their perceived importance to the consumer (Casler, 1992).

In order to determine sample weights, the Bureau of Labor Statistics currently tracks the spending patterns of consumers by using three types of indices: CPI-W, $\mathrm{CPI}-\mathrm{U}$ and C-CPI-U. The Consumer Price Index (CPIW) for Urban Wage Earners and Clerical Workers index, which is the original index, seeks to collect data on households where 50 percent or more of household income comes from wages and clerical workers' earnings (Reed \& Stewart, 2014). The CPI-W represents approximately 30 percent of the total U.S. population (Reed \& Stewart, 2014). The CPI-U (which has been used since 1978) is a broader and more commonly used index that is based on the expenditures of residents of urban or metropolitan areas. Professionals, the self-employed, the poor, the unemployed, and retired people, as well as urban wage earners and clerical workers are all included in this survey, which is generalizable to approximately $90 \%$ of the total U.S. population (Reed \& Stewart, 2014).

Chained CPI-U for All Urban Consumers (or C-CPI$U$ ), which also represents the urban population as a whole, uses the same market basket of represented goods and services as the CPI-W and the CPI-U. However, a different formula is used to determine item weights (Bureau of Labor Statistics, 2015). If a consumer's primary goods and services becomes too pricey or unavailable, the formula used in the chained $\mathrm{CPI}$ attempts to account for the consumer's ability to switch to substitute goods and services (Bureau of Labor Statistics, 2015). This index is viewed as a more conservative measure of price increases (Bureau of 
Labor Statistics, 2015). People living in rural nonmetropolitan areas, in farm households, on military installations, in religious communities, and in institutions such as prisons and mental hospitals are not included in any of the CPI indices (Reed \& Stewart, 2014; Bureau of Labor Statistics, 2015).

The information garnered from the CPI is used to determine the cost of represented goods and services in the United States. This information is used by federal and state agencies such as the Center for Medicare and Medicaid Services (CMS), the Social Security Administration and by state pension agencies to make cash flow and cost of living adjustments (Bureau of Labor Statistics, 2015). CPI is also used to identify the presence of inflation, deflation or price stability in the market (Evans, 2013; Higgins \& Verbrugge, 2015).

Inflation is defined as a sustained increase in the general level of prices for goods and services in an economy (CPI Inflation rate of $2.5 \%$ or higher). Inflation occurs when there is a decrease in the availability of demanded goods and services (McKenna, 1977; Evans/Harvey Mudd College, 2013). In the short run, the demand for these services can become greater than the supply of these services (McKenna, 1977; Casler, 1992). Due to this occurrence, suppliers will increase the prices of the goods and services. However, over time, the cost of the goods and services will increase beyond the purchasing power of the consumer (demander of goods/services). Due to this increase, the purchasing power of the demander will eventually decrease and the average standard of living will start to decline (McKenna, 1977; Casler, 1992).

Deflation is defined as the sustained decrease in the general level of prices for goods and services (CPI Inflation rate of $<0 \%$ ). Deflation usually occurs because of a reduction in personal, or government spending, which can occur in periods of high or increasing unemployment (Shilling, 1999; Evans, 2013). The reduction in spending has the ability to decrease demand which in turn reduces the price for these goods and services. As a result, suppliers can no longer afford to supply items at the decreased price. These suppliers will start to reduce their supply and in turn lay off their employees. This has the potential to exasperate a situation where there is already high or growing unemployment (Shilling, 1999). As a result of these potential occurrences, the presence of deflation is associated with a poorly performing economy (Atkeson \& Kehoe, 2004; Evans, 2013)
A price stable environment, CPI inflation rate between $0-2.5 \%$, is identified by low economic inflation and constant market growth (Akerlof, Dickens, \& Perry, 1996; Evans, 2013). In a price stable environment, the price of goods and services remain relatively stable in a market and there is relatively little economic fluctuations. As a result of the consistency in the market, price stable environments are also associated with high levels of economic activity and employment (Akerlof, Dickens, \& Perry, 1996).

\section{Unemployment}

Unemployment occurs when a person who is actively seeking employment but is unable to find work. The most frequently cited measure of unemployment is the unemployment rate, which is a measure of the number of unemployed persons/ people in the labor force (Layard, Nickell, \& Jackman, 1991). In any economy, there is a rate of unemployment that is expected when an economy is functioning at full capacity. This is known as the natural rate of unemployment, which is estimated to be at about five percent (Hall, 1979; Blanchard \& Katz, 1997; Shah, 2012).

There are three commonly used categories of unemployment: structural unemployment, frictional unemployment, and cyclical unemployment. Structural unemployment occurs when technological changes in the market creating demands for certain types of skilled labor, while reducing the demand for other types of skilled labor (Leonard, 1986; Casler, 1992). Frictional unemployment occurs when workers are voluntarily between jobs. With this type of unemployment, an individual leaves the workforce to find another job, which better suites their lifestyle or career goals (Leonard, 1986; Casler, 1992). Cyclical unemployment occurs when they are downturns in the overall business activity (Abraham \& Katz, 1986; Casler, 1992). There is an inverse relationship between business cycles and cyclical unemployment. When the business cycle is at its peak, cyclical unemployment will be low. If the business cycle is low, then cyclical unemployment will be high (Casler, 1992).

The unemployment rate is often used as a measure of health of the economy. In times of low unemployment $(<5 \%)$, consumers have greater opportunities to work or to find jobs which will give them more access to money and more opportunity to demand normal goods and services; while in times of high unemployment, consumers have less opportunity 
to work or to find jobs which lead to less money and less opportunity to demand normal goods/services (Layard, Nickell, \& Jackman, 1991).

\section{SUGGESTED ANALYTIC APPROACHES}

\section{Regression Analysis}

Due to the complexity associated with modeling health risk behaviors such as drug abuse we propose that a binary logistic regression model may be used. A model of this nature will allow the researcher to analyze the influence of the predictors of interest (unemployment rate, $\mathrm{CPI}$ ), while simultaneously controlling for demographic (age, gender, race/ethnicity) and sociodemographic (marital status, occupation, income level) variables. A binary logistic regression model is defined as as $z=\beta 0+\beta_{1} X_{1}+\beta_{2} X_{2}$ $+\beta_{k} X_{k}$. predicts the log odds of the dependent variable $(z)$. The log odds of the dependent variable (z) encompass two categories ( 1 and 0 ). One is defined as the value of the dependent variable, and zero is used as the reference value (Garrision, 2009). For purposes of this analysis, the dependent variable could be the use (or abuse) of an illegal drug over the past year. The individuals who engaged in this behavior would be categorized as a (1) and the individuals who did not engage would be placed in the reference category (0). On the opposite side of the equation there is $\beta$ o, which is the constant. Listed after the constant, there is the possibility of having $\mathrm{k}$ coefficients and $\mathrm{k}$ independent variables. Based on the theoretical nature of the investigation these predictors are also allowed to interact (Garrision, 2009). The allowance of $k$ independent variables allows the opportunity to test for associations while controlling for multiple predictors simultaneously (Hennekens \& Buring, 1987; Garrision, 2009). We believe that a model of this nature can be used to successfully analyze the influence of macroeconomic indicators which controlling for intrapersonal and interpersonal factors as they relate to drug use or abuse.

\section{Time-Series Analysis}

In addition, since the goal is to focus on the influence of differing macroeconomic measures over several time periods, the proposed investigation will require the use of a time series cross-sectional type of design. This type of design involves pooling of several cross sectional data sets, which were taken at different time periods (i.e., years), into one data set. The effect of combining the cross sectional data sets provides for certain advantages. The first being the opportunity to analyze a large pooled data set (Beck, 2006). The larger sample will increase the precision of the estimators and will increase power for detecting significant associations (Wooldridge, 2009). In addition, the cross-sectional time series design allows the opportunity to account for the influence of unobserved time-specific variables (or events), which have the potential to influence outcomes (Wooldridge, 2009). For example, major watershed moments such as the 2001 terrorist attacks may potentially impact the mindsets, health behaviors, and health outcomes of the population and thus can unduly impact the results from a cross-sectional study that uses data from that specific year. The impacts of these incidents are then mitigated when surveys from these eventful years are pooled with surveys from different years, and the model control for "year effects" to account for year-specific characteristics that may bias the main results of interest. As a result of these methods we will have a more accurate analysis. There are, however, some limitations with this design. The logistic regression model requires adherence to the independence assumption, which states that the information taken from one observation is independent of information taken from any other observation. If this assumption fails then the observations are believed to be correlated and the chance of making type 1 error increases (Beck, 2006). The independence assumption violation can be avoided by placing time corresponding dummy variables in the model to represent all the years (except the first year) from which the sample was drawn (Beck \& Katz, 1995; Beck, Katz, \& Tucker, 1997, p. 3). This strategy can be incorporated into the proposed analysis by placing time invariant dummy variables from selected years into the regression model.

\section{Stratification: Effect Modification}

Hypothesis six which focuses on the effect of CPI on drug usage as moderated by an individual's income attainment will require the use of a study design which takes into account the possible effect of the third variable. This type of analysis can be accomplished by stratifying the study sample into low income, middle income and upper income individuals.

Stratification is a strategy that can be used to control for confounding and/or determine the presence of effect modification (Gordis, 2000). Confounding is defined as the occurrence of an effect, which distorts the true relationship between the predictor variable and the outcome variable (Gordis, 2000). Stratification 
controls for confounding by creating strata where homogenous groups of individuals are placed (e.g., stratum of all women, stratum of people who have health insurance, stratum of single individuals with no dependents). Due to the lack of variability resulting from the homogenous composition of the stratified population, confounding is not allowed to occur (Hennekens \& Buring, 1987; Gordis, 2000).

In addition to using stratification to control for confounding, this analysis will employ the use of multivariate logistic regression. The use of multivariate logistic regression will allow for measures of association while simultaneously controlling for a number of potential confounders (Hennekens \& Buring, 1987; Garrision, 2009). The use of stratification will in turn be used to identify the presence of effect modification. Effect modification is identified when the association between the predictor and outcome variable varies across a third factor. With the analysis of effect modification, the goal is to describe how the association of interest is modified by a third factor (Hennekens \& Buring, 1987).

\section{SUMMARY}

In summation, we hope that this discussion will provide a stimulus for new and more creative avenues for drug policy research. As noted by Duncan, Nicholson, White and Ellis-Griffith (2014), the current "war on drugs", or more precisely drug prohibition, has been the dominant global policy for the past century. Drug use and drug abuse, however, remain relatively unabated (Blackwell, 2014; Drucker, 1999; Levine, 2003). For example, the U.S. alone has devoted approximately one trillion dollars (US) to this war since just 1980 (Mendoza, 2010; Drug Policy Alliance, 2015). Given that human beings have been using drugs for as long as the historical record indicates (Crocq, 2007; Nicholson, Duncan \& White, 2002; Westermeyer, 1988), it is not surprising that issues related to drug behavior have not dramatically changed overnight.

Today, the basis of drug policy seems to be shifting away from prohibition, even if intermittently or sporadically, to a more diverse range of approaches (Duncan, 1994). These include harm reduction, decriminalization, legalization, and such related practices as medical marijuana, heroin maintenance, etc. This greater diversity of approaches requires a broader examination of the causes of drug use and abuse.
The policy approach of prohibition has been founded in large part on the perception of drug users as persons of weak moral character or poor self-control and of the prohibited drugs as overwhelmingly powerful, dangerous, and even evil (Hoffmann, 1990; Room, 2005). Even in this Century, physician/essayist Theodore Dalrymple (2006) gained considerable attention for his reassertion of the traditional view that the origins of drug addiction lie in frailties of the addict's character and that addiction, therefore, can only be treated by a mixture of coercion and appeals to morality and self-interest. Specifically in the policy field, Hobson (2014) notes that the U.N. Single Covenant on Narcotic Drugs is unique among international conventions in its emphasis on combating "evil" as its raison d'etre.

The National Research Council (2001, p. 37) has pointed out that "A basic understanding of the determinants of drug use, especially of abuse and addiction, is a prerequisite to serious discussion of drug control policy." In contrast to the focus on individual factors in drug use and abuse that suited the prohibition model, the broader based approaches being considered in place of prohibition requiring a basic understanding to address a complex system of causes affecting drug taking (Galea, Hall, \& Kaplan, 2009; National Research Council (2010). Unfortunately, it appears that, "to date, scientific research provides limited support and clarity to the complex system which results in substance use and its problems" (Birckmayer, Holder, Yacoubian, \& Friend, 2004). Exploration of options for a wider range of policy responses to non-medical drug taking will require the consideration of a wider range of correlates and determinants of drug use and abuse (Gerstein \& Green, 1993, pp. 45-67; Birckmayer, Holder, Yacoubian, \& Friend, 2004; National Research Council, $2001 \&$ 2010). The relationship between the economy and drug consumption is one of those areas that should merit such examination. These authors argue that now is the time to do more research on economics and drugs, addressing the paucity noted by The Economist (Drug use and abuse: The fire next time, 2011). It is to be hoped that this review will stimulate research in this area.

\section{REFERENCES}

Abraham, Katharine G., and Lawrence F. Katz. 1986. "Cyclical Unemployment: Sectoral Shifts or Aggregate Disturbances?" Journal of Political Economy 94(3):507-522. http://dx.doi.org/10.1086/261387 
Akerlof, G. A., Dickens, W. R., \& Perry, G. L. 1996. "The macroeconomics of low inflation." Brookings Papers on Economic Activity (1):1-76. http://dx.doi.org/10.2307/2534646

American Psychiatric Association. 1994. Diagnostic and Statistical Manual of Mental Disorders, Fourth Edition (DSM-IV). Washington, DC: American Psychiatric Association.

Atkeson, Andrew, and Patrick J. Kehoe. 2004. "Deflation and Depression: Is There an Empirical Link?" American Economic Review 94(2):99-103. http://dx.doi.org/10.1257/0002828041301588

Bachman, Jerald, Lloyd Johnston, Patrick M. O'Malley, and John E. Schulenberg, 12006. The Monitoring the Future project after thirty-two years: Design and procedures (Monitoring the Future Occasional Paper No. 64). Ann Arbor, Ml: University of Michigan.

Beck, Nathaniel. 2006. Time-series -- Cross- section Methods. New York: New York University. Retrieved from http://as.nyu.edu/docs/lO/2576/beck.pdf

Beck, Nathaniel and Jonathan N. Katz (1995). "What To Do (and Not To Do) with Times-Series Cross-Section Data." American Political Science Review 89:634-647. http://dx.doi.org/10.2307/2082979

Beck, Nathaniel, Jonathan N. Katz, and Richard Tucker. (1997). Beyond Ordinary Logit: Taking Time Seriously in Binary Time Series Cross Sectional Models. Social Science Working Paper 1017, California Institute of Technology, Division of the Humanities and Social Sciences. Retrieved from http://citeseer. ist.psu.edu/viewdoc/download;jsessionid=650E CF3BD285C82B9DFD8D627EA3954A?doi=10.1.1.28.3132\& rep=rep $1 \&$ type $=$ pdf

Bellis, Mark A., Karen Hughes, Michela Morleo, Karen Tocque, Sara Hughes, Tony Allen, Dominic Harrison, and Eduardo FeRodriguez. 2007. "Predictors of Risky Alcohol Consumption in Schoolchildren and Their Implications for Preventing Alcohol-related Harm." Substance Abuse Treatment, Prevention and Policy 2:15-24.

http://dx.doi.org/10.1186/1747-597X-2-15

Birckmayer, Johanna D., Harold D. Holder, George S. Yacoubian, and Karen B. Friend. 2004. "A General Causal Model to Guide Alcohol, Tobacco, and Illicit Drug Prevention: Assessing the Research Evidence." Journal of Drug Education 34(2):121-153. http://dx.doi.org/10.2190/PYL2-FF8N-6B6C-A57R

Blackwell, J. Michael. 2014. "Costs and Consequences of US Drug Prohibition for the Peoples of Developing Nations." Indiana International \& Comparative Law Review 24(3):665-692.

Blanchard, Olivier, and Lawrence F. Katz. 1997. "What We Know and Do Not Know About the Natural Rate of Unemployment." Journal of Economic Perspectives 11(1):51-72. http://dx.doi.org/10.1257/jep.11.1.51

Bor, Jacob, Sanjay Basu, Adam Coutts, Martin McKee, and David Stuckler (2013). "Alcohol use during the great recession of 2008-2009." Alcohol and Alcoholism 48(3):343-348. http://dx.doi.org/10.1093/alcalc/agt002

Brandon, Emily. 2013, April 29. "How the Chained CPI Affects Social Security Payments - US News." Retrieved from http://money.usnews.com/money/retirement/articles/2013/04/ 29/how-the-chained-cpi-affects-social-security-payments

Brener, Nancy D., Laura Kann, Shari L. Shanklin, Steven A. Kinchen, Danice K. Eaton, Joseph Hawkins, and Katherine H. Flint. 2013. "Methodology of the youth risk behavior surveillance system -- 2013." MMWR Recommendations and Reports, 62(rr-1):1-20.

Brenner, M. Harvey. 1967. "Economic change and mental hospitalization: New York State, 1910-1960." Social Psychiatry, 2(4):180-188. http://dx.doi.org/10.1007/BF00578054
Brenner, M. Harvey. 1971. Time series analysis of the relationships between economic and social indicators. Springfield, VA: National Technical Information Service.

Brenner, M. Harvey. 1973. Mental illness and the economy. Cambridge, MA: Harvard University Press.

Brenner, M. Harvey. 1975. "Trends in alcohol consumption and associated illnesses. Some effects of economic changes." American Journal of Public Health, 65(12):1279-1292. http://dx.doi.org/10.2105/AJPH.65.12.1279

Brenner, M. Harvey. 1976. Estimating the social costs of national economic policy: Implications for mental and physical health and criminal aggression. Joint Economic Committee of the U.S. Congress. Washington, D.C. : U.S. Government Printing Office.

Brenner, M. Harvey. 1979. "Mortality and the national economy: A review, and the experience of England and Wales, 1936-76." The Lancet 314(8142):568-573. http://dx.doi.org/10.1016/S0140-6736(79)91626-X

Brenner, M. Harvey. 1984. Estimating the effects of economic change on national health and social well being. Joint Economic Committee of the U.S. Congress. Washington, D.C.: U.S. Government Printing Office.

Brenner, M. Harvey. And R. T. Swank. 1986. "Homicide and economic change: Recent analyses of the Joint Economic Committee report of 1984." Journal of Quantitative Criminology, 2(1):81-103. http://dx.doi.org/10.1007/BF01064597

Brenner, M. Harvey. 2005. "Commentary: Economic growth is the basis of mortality rate decline in the 20th century -Experience of the United States 1901-2000." International Journal of Epidemiology, 34(6):1214-1221. http://dx.doi.org/10.1093/ije/dyi146

Bureau of Labor Statistics. (2015, December 2). Consumer Price Index Frequently Asked Questions. Washington, DC: author. Retrieved from http://www.bls.gov/cpi/cpifaq.htm

Bureau of Labor Statistics. (2015). The consumer price index. Washington, DC: author. Retrieved from: http://www.bls.gov/ opub/hom/pdf/homch17.pdf

Cahalan, Don, I. H. Cisin, and Crossley, H. M. (1969). American drinking practices: $A$ national survey of drinking behavior and attitudes. New Brunswick, NJ: Rutgers Center of Alcohol Studies.

Casler, Stephen D. 1992. Introduction to Economics. New York, NY: HarperPerennial.

Catalano, Ralph. 1997. "An Emerging Theory of the Effect of Economic Contraction on Alcohol Abuse in the United States." Social Justice Research 10(2):191-201. http://dx.doi.org/10.1007/BF02683312

Catalano, Ralph, Karen Rook, and David Dooley 1986. "Labor markets and help-seeking: A test of the employment security hypothesis." Journal of Health and Social Behavior 27:277287.

http://dx.doi.org/10.2307/2136747

Crawford, Alex, Martin A. Plant, Norman Kreitman, and Richard W. Latcham. 1987. "Unemployment and Drinking Behavior: Some Data From a General Population Survey of Alcohol Use." British Journal of Addiction, 82(9):1007-1016. http://dx.doi.org/10.1111/j.1360-0443.1987.tb01561.x

Crocq, Marc-Antoine. 2007. "Historical and Cultural Aspects of Man's Relationship with Addictive Drugs." Dialogues in Clinical Neuroscience 9(4):355-361.

Dalrymple, Theodore. 2006. Romancing Opiates: Pharmacological Lies and the Addiction Bureaucracy. New York: Encounter Books.

De Goeij, Moniek C.M., Marc Suhrcke, Veronica Toffolutti, Dike van de Mheen, Tim M. Schoenmakers, and Anton E. Kunst (2015). "How Economic Crises Affect Alcohol Consumption 
and Alcohol-related Health Problems: A Realist Systematic Review." Social Science and Medicine 131:131-146. http://dx.doi.org/10.1016/j.socscimed.2015.02.025

Dee, Thomas S. 2001. "Alcohol abuse and economic conditions: Evidence from repeated cross-sections of individual level data." Health Economics, 10(4):257-270. http://dx.doi.org/10.1002/hec.588

Dom, Geert, Jerzy Samochowiec, Sara Evans-Lacko, Kristian Wahlbeck, Guido Van Hal, and David McDaid(2016). "The Impact of the 2008 Economic Crisis on Substance Use Patterns in the Countries of the European Union." International Journal of Environmental Research and Public Health 13:122-132. http://dx.doi.org/10.3390/ijerph13010122

Drucker, Ernest. (1999). "Drug Prohibition and Public Health: 25 Years of Evidence." Public Health Reports, 114(1):14-29. http://dx.doi.org/10.1093/phr/114.1.14

Drug Policy Alliance. 2015. The Federal Drug Control Budget: New Rhetoric, Same Failed Drug War. Viewed Oct. 18, 2015 at http://www.drugpolicy.org/sites/default/files/DPA_Fact_sheet Drug_War_Budget_Feb2015.pdf

Drug Use and Abuse: The Fire Next Time. The Economist, Nov 19, 2011. http://www.economist.com/node/21538765

Duncan, David F. 1988. Epidemiology: Basis for Disease Prevention and Health Promotion. New York: Macmillan.

Duncan, David F. 1994. "Editorial: Rethinking Drug Policy Options -Getting Beyond Prohibition Versus Legalization." Substance Abuse, 15:197-198.

Duncan, David F., Thomas Nicholson, John B. White, and Greg EllisGriffith. 2014. "A Brief History of Prohibition and Treatment Solutions for Substance Abusers." International Journal of Criminology and Sociology 3:186-199. http://dx.doi.org/10.6000/1929-4409.2014.03.17

Dunham, H. Warren. (1965). Community and Schizophrenia. Detroit: Wayne State University Press.

Dunham, H. Warren., Patricia Phillips, and Barbara Srinivasan. 1966. "A Research Note on Diagnosed Mental Illness and Social Class." American Sociological Review 31:223-227. http://dx.doi.org/10.2307/2090908

Ettner, S. L. (1997)."Measuring the Human Cost of a Weak Economy: Does Unemployment Lead to Alcohol Abuse?" Social Science and Medicine 44(2):251-260. http://dx.doi.org/10.1016/S0277-9536(96)00160-8

European Monitoring Centre for Drugs and Drug Addiction (2010). The State of the Drugs Problem in Europe. Luxembourg: Publications Office of the European Union. doi:10.2810/ 33349 http://www.emcdda.europa.eu/attachements.cfm/ att_120104_EN_EMCDDA_AR2010_EN.pdf

Evans, Gary R. (2013). Inflation and Deflation. Retrieved from http://pages.hmc.edu/evans/inflation.pdf

Faris, Robert E. Lee, and H. Warren Dunham. 1939. Mental Disorders in Urban Areas: An Ecological Study of Schizophrenia and Other Psychoses. Chicago: University of Chicago Press.

Feinstein, J. S. 1993. "The Relationship between Socio-economic Status and Health: A Review of the Literature." Milbank Quarterly 71:279-322. http://dx.doi.org/10.2307/3350401

Feldstein, Martin Stuart 1999. The Costs and Benefits of Price Stability: Papers presented at an NBER Conference held at the Federal Reserve Bank of New York on Feb. 20 - 21, 1997. Chicago: The University of Chicago Press. http://dx.doi.org/10.7208/chicago/9780226241760.001.0001

Forbes, J. F., and A. McGregor. 1984. "Unemployment and Mortality in Post-war Scotland." Journal of Health Economics 3:219257.

http://dx.doi.org/10.1016/0167-6296(84)90013-4
Freeman, D. G. 1999. "A Note on Economic Conditions and Alcohol Problems." Journal of Health Economics 18:661-670. http://dx.doi.org/10.1016/S0167-6296(99)00005-3

Freeman, D. G. 2001. "Beer and the Business Cycle." Applied Economics Letters 8:51-54. http://dx.doi.org/10.1080/135048501750041295

Frone, M. R. (2015, December 21). "The Great Recession and Employee Alcohol Use: A U.S. Population Study." Psychology of Addictive Behaviors. Online publication. http://dx.doi.org/10.1037/adb0000143

Galea, S., C.Hall, and G. A. Kaplan. 2009. "Social Epidemiology and Complex System Dynamic Modelling as Applied to Health Behaviour and Drug Use Research." International Journal of Drug Policy 20(3):209-216. http://dx.doi.org/10.1016/j.drugpo.2008.08.005

Galea, Sandro, and David Vlahov. 2002. Social Determinants and the Health of Dug Users: Socioeconomic Status, Homelessness, and Incarceration. Public Health Reports 117(Suppl 1):S135-S145.

Gascon, D. J., and H. A. Spiller. 2009. Relationship of Unemployment Rate and Rate of Opiate Exposure in Kentucky. Journal of Psychoactive Drugs 41(1):99-102. http://dx.doi.org/10.1080/02791072.2009.10400679

Gerdtham, U.-G., and C. J. Ruhm. 2006. Deaths Rise in Good Economic Times: Evidence from the OECD. Economics and Human Biology 4(3):298-316. http://dx.doi.org/10.1016/j.ehb.2006.04.001

Gerstein, Dean R., \& :Lawrence W. Green. 1993. Preventing Drug Abuse: What Do We Know? Washington: National Academies Press.

Gravelle, Hugh S. E., Gillian Hutchinson, and Jon Stern. 1981 "Mortality and Unemployment: A Critique of Brenner's Time Series Analysis." The Lancet 9(26):675-679. http://dx.doi.org/10.1016/S0140-6736(81)91007-2

Hall, Robert E. (1979). A Theory of the Natural Unemployment Rate and the Duration of Employment. Journal of Monetary Economics 5(2):153-169. http://dx.doi.org/10.1016/0304-3932(79)90001-1

Hennekens, Charles H., Julie E. Buring, and Sherry L. Mayrent 1987. Epidemiology in Medicine. Boston: Little, Brown.

Higgins, Amy, and Randal Verbrugge. 2015. Is a Nonseasonally Adjusted Median CPI a Useful Signal of Trend Inflation? (2015-13) Retrieved from Economic Commentary/ Federal Reserve Bank of Cleveland website: https://www. clevelandfed.org/en/newsroom-and-events/publications/ economic-commentary/2015-economic-commentaries/ec201513-is-nonseasonally-adjusted-mcpi-signal.aspx

Hobson, Christopher (2014). "Challenging 'Evil': Continuity and Change in the Drug Prohibition Regime." International Politics 51:525-542. http://dx.doi.org/10.1057/ip.2014.17

Hoffman, Joan. 1997. "Macroeconomic Indicators and New York City Women's Drug Arrests." Social Justice, 24(1):82-106.

Hoffmann, John P. 1990. "The Historical Shift in the Perception of Opiates: From Medicine to Social Menace." Journal of Psychoactive Drugs, 22(1):53-62. http://dx.doi.org/10.1080/02791072.1990.10472197

Hollingshead, August B., and Frederick C. Redlich. 1958. Social Class and Mental IIIness. New York: Wiley. http://dx.doi.org/10.1037/10645-000

Humensky, J. L. 2010. "Are Adolescents with High Socioeconomic Status More Likely to Engage in Alcohol and Illicit Drug Use in Early Adulthood?" Substance Abuse Treatment, Prevention, and Policy 5(1):19. http://dx.doi.org/10.1186/1747-597X-5-19

Irwin, Neil (2015, October 24). The 57-Year-Old Chart That Is Dividing the Fed. The New York Times. Retrieved from http://www.nytimes.com/2015/10/25/upshot/the-57-year-oldchart-that-is-dividing-the-fed.html 
Johnston, Lloyd, Patrick M. O'Malley, Jerald G. Bachman, and John E. Schulenberg. 2013. Monitoring the Future National Survey Results on Drug Use, 1975-2011: Volume I, Secondary School Students. Ann Arbor, MI: University of Michigan.

Joyce, Theodore J., and Naci H. Mocan, N. 1993. "Unemployment and Infant Health: Time-Series Evidence from the State of Tennessee." Journal of Human Resources 28(1):185-203. http://dx.doi.org/10.2307/146093

Kandel, Denise B., \& Kazuo Yamaguchi 1987. "Job Mobility and Drug Use: An Event History Analysis." American Journal of Sociology 93:836-878. http://dx.doi.org/10.1086/228585

Karanikolos, Marina, Philipa Mladovsky, Jonathan Cylus, Sarah Thomson, Sanjay Basu, David Stuckler, Johan P. Mackenbach, and Martin McKee. (2013). "Financial Crisis, Austerity, and Health in Europe." Lancet 381(9874):13231331. http://dx.doi.org/10.1016/S0140-6736(13)60102-6

Kleinbaum, David G., Mitchell Klein, and Erica R. Pryor (2002). Logistic regression: A self-learning text. New York: Springer.

Kruger, Niklas A., and Mikael K Svensson. 2010. "Good Times are Drinking Times: Empirical Evidence on Business Cycles and Alcohol Sales in Sweden 1861-2000." Applied Economics Letters 17:543-546.

http://dx.doi.org/10.1080/13504850802167215

Lahelma, Eero, Risto Kangas, and Kristina Manderbacka. 1995. "Drinking and Unemployment: Contrasting Patterns Among Men and Women." Drug and Alcohol Dependence, 37(1):7182. http://dx.doi.org/10.1016/0376-8716(94)01054-O

Lantz, Paula M., and Andrew Pritchard. 2010. "Socioeconomic Indicators that Matter for Population Health." Preventing Chronic Disease 7(4):A74. http://www.cdc.gov/pcd/issues/ 2010/jul/09_0246.htm

Layard, P. Richard G., Stephen J. Nickell, and Richard Jackman. 1991. Unemployment: Macroeconomic Performance and the Labour Market. Oxford, England: Oxford University Press.

Leonard, Jonathan S. 1986. In the Wrong Place at the Wrong Time: The Extent of Frictional and Structural Unemployment. Cambridge, MA: National Bureau of Economic Research. http://dx.doi.org/10.3386/w1979

Levine, Harry G. 2003. "Global Drug Prohibition: Its Uses and Crises." International Journal of Drug Policy 14(2):145-153. http://dx.doi.org/10.1016/S0955-3959(03)00003-3

Luoto, Riitta, Kari Poikolanen, and Anttii Uutela. 1998. "Unemployment, Sociodemographic Background and Consumption of Alcohol Before and During the Economic Recession of the 1990s in Finland." International Journal of Epidemiology $27: 623-629$. http://dx.doi.org/10.1093/ije/27.4.623

Maddock, Jay E., Meghan McGurk, and Lee Thomas (2015). "Attitudes of Policy Makers in Hawaii Toward Public Health and Related Issues Before and After an Economic Recession in the United States." Frontiers in Public Health, 3(146):1-6. http://dx.doi.org/10.3389/fpubh.2015.00146

Makela, Pia. (1999). Alcohol-related Mortality During an Economic Boom and Recession. Contemporary Drug Problems 26:369390

Martin. Barbara A., Thomas P. McCoy, Heather Champion, Maria T. Parries, Robert H. DuRant, Ananda Mitra, and Scott D.Rhodes. 2009. The Role of Monthly Spending Money in College Student Drinking Behaviors and their Consequences. Journal of American College Health 57(6):587-596.

http://dx.doi.org/10.3200/JACH.57.6.587-596

McAvinchey, Ian D. 1988. A Comparison of Unemployment, Income and Mortality Interaction for five European Countries. Applied Economics 20(4):453-471. http://dx.doi.org/10.1080/00036848800000057
McKenna, Joseph P. (1977). Aggregate economic analysis (5th ed.). Hinsdale, IL: Dryden.

Mendoza, M. May 13, 2010. US Drug War Has Met None of Its goals. Associated Press.

Mounteney, J., \& Griffiths, P. (2014). Increasing Complexity in European Drug Use: Highlights from the EMCDDA's 2014 European Drug Report. Drugs: Education, Prevention and Policy 21(6), 482-483.

http://dx.doi.org/10.3109/09687637.2014.963516

Mustonen, H., Paakannen, P., and Simpura, J. (1994). Drinking Habits among the Employed and Unemployed. Nordisk Alkoholtidskrift, 11, 21-34.

National Research Council (2001). Informing America's Policy on Illegal Drugs: What We Don't Know Keeps Hurting Us. Washington, DC: The National Academies Press, 2001.

National Research Council (2010). Understanding the Demand for Illegal Drugs. Washington, DC: The National Academies Press.

Nicholson, Thomas, David F. Duncan, and John B. White. 2002. Is Recreational Drug Use Normal? Journal of Substance Use 7:116-123. http://dx.doi.org/10.1080/14659890209169340

Patton, Michael. 2013. "Inflation Or Deflation: Which Is The Greater Risk?" Retrieved from http://www.forbes.com/sites/ mikepatton/2013/07/01/the-truth-behind-the-feds-monetaryexpansion/

Pearlin, Leonard I., and Clarice W. Radabaugh. 1976. Economic Strains and the Coping Functions of Alcohol. American Journal of Sociology 82:652-663. http://dx.doi.org/10.1086/226357

Quaglio, GianLuca, Theodoros Karapiperis, Lieve Van Woensel, Elleke Arnold, and David McDaid (2013). "Austerity and health in Europe." Health Policy 113(1):13-19. http://dx.doi.org/10.1016/j.healthpol.2013.09.005

Reed, Stephen B., and Kenneth J. Stewart. 2014. "Why does BLS provide both the CPI-W and CPI-U?" Beyond the Numbers: Prices and Spending 3(5):1. Retrieved from http://www.bls. gov/opub/btn/volume-3/why-does-bls-provide-both-the-cpi-wand-cpi-u.htm

Rippy, Darren. 2012. "Current Price Topics: The Experimental Consumer Price Index for Older Americans (CPI-E)." Focus on Prices and Spending 2(15):1. Retrieved from http://data. bls.gov/cgi-bin/print.pl/opub/focus/volume2_number15/ cpi_2_15.htm

Rippy, Darren. 2014. "The First Hundred Years of the Consumer Price Index: A Methodological and Political History." Monthly Labor Review 137:1. Retrieved from http://www.bls.gov/ opub/mlr/2014/article/the-first-hundred-years-of-theconsumer-price-index.htm

Ritson, Bruce. 2003. The 1999 ESPAD Report. The European School Survey Project on Alcohol and Other Drug Use among Students in 30 European Countries. Alcohol and Alcoholism, 38(1):99. http://dx.doi.org/10.1093/alcalc/agg034

Room, Robin. (2005). Stigma, social inequality and alcohol and drug use. Drug and Alcohol Review 24(2):143-155. http://dx.doi.org/10.1080/09595230500102434

Ruhm, Christopher J. 1995. Economic Conditions and Alcohol Problems. Journal of Health Economics 14:583-603. http://dx.doi.org/10.1016/0167-6296(95)00024-0

Ruhm, Christopher J. (2000). Are Recessions Good for Your Health? Quarterly Journal of Economics 617-650. http://dx.doi.org/10.1162/003355300554872

Ruhm, Christopher J. (2005). Commentary: Mortality Increases During Economic Upturns. International Journal of Epidemiology 34:1206-1211. http://dx.doi.org/10.1093/ije/dyi143 
Seeman, Melvin, Alice Z. Seeman, and Art Budros. (1988). Powerlessness, Work, and Community: A Longitudinal Study of Alienation and Alcohol Use. Journal of Health and Social Behavior 29:185-198.

http://dx.doi.org/10.2307/2137031

Shah, N. 2012, September 7. "Decoding 'Natural' Rate of Unemployment." The Wall Street Journal. Retrieved from http://www.wsj.com/articles/SB100008723963904436860045 77635652468415814

Shilling, A. Gary. 1999. Deflation: How to survive and thrive in the coming wave of deflation. New York: McGraw-Hill.

Smart, Reginald G., and Glenn F. Murray. 1983). Drug Abuse and Affluence in Five Countries: A Study of Economic and Health Conditions, 1960-1975. Drug and Alcohol Dependence 11:297-307. http://dx.doi.org/10.1016/0376-8716(83)90021-2

Smart, Reginald G., and Glenn F. Murray. 1985). Narcotic Drug Abuse in 152 Countries: Social and Economic Conditions as Predictors. International Journal of the Addictions, 20(5):737749.

http://dx.doi.org/10.3109/10826088509044293

Søgaard, JES. 1992. Econometric Critique of the Economic Change Model of Mortality. Social Science \& Medicine 34(9):947-957. http://dx.doi.org/10.1016/0277-9536(92)90125-A

Stern, J. (1983). The Relationship Between Unemployment, Morbidity, and Mortality in Britain. Population Studies 37:6174.

http://dx.doi.org/10.1080/00324728.1983.10405924

Stuckler, David, Sanjay Basu, Marc Suhrcke, and Martin McKee. 2009. "The Health Implications of Financial Crisis: A Review of the Evidence." The Ulster Medical Journal 78(3):142-145. http://dx.doi.org/10.1016/S0140-6736(09)61124-7

Stuckler, David, Sanjay Basu, Marc Suhrcke, Adam Coutts, and Martin McKee. 2009. The public health effect of economic crises and alternative policy responses in Europe: an empirical analysis. The Lancet 374(9686):315-323.
Substance Abuse and Mental Health Services Administration. (2012). Comparing and Evaluating Youth Substance Use Estimates from the National Survey on Drug Use and Health and Other Surveys. HHS Publication No. SMA 12-4727, Methodology Series M-9. Rockville, MD: Substance Abuse and Mental Health Services Administration.

Tapia Granados, Jose A. (2005). Increasing Mortality during the Expansions of the US Economy, 1900-1996. International Journal of Epidemiology 34:1194-1202. http://dx.doi.org/10.1093/ije/dyi141

Tapia Granados, Jose A., and Ionides, Edward L. (2008). The Reversal of the Relation between Economic Growth and Health Progress: Sweden in the 19th and 20th Centuries. Journal of Health Economics 27(3):544-563. http://dx.doi.org/10.1016/j.jhealeco.2007.09.006

The Economist (2011). Drug Use and Abuse: The Fire Next Time. The Economist, p.

The Economist (2015). Pocket World in Figures. London: Profile Books.

United Nations Office on Drugs and Crime (2015). World Drug Report 2015. Geneva: World Health Organization,

Wagstaff, Adam. 1985. Time Series Analysis of the Relationship between Unemployment and Mortality: A Survey of Econometric Critiques and Replications of Brenner's Studies. Social Science \& Medicine 21(9):985-996. http://dx.doi.org/10.1016/0277-9536(85)90420-4

Westermeyer, Joseph. 1988. The Pursuit of Intoxication: Our 100 Century-old Romance with Psychoactive Substances. American Journal of Drug and Alcohol Abuse 14(2):175-187. http://dx.doi.org/10.3109/00952999809001545

Wooldridge, J. M. (2009). Introductory econometrics: $A$ modern approach (4th ed.). Mason, $\mathrm{OH}$ : South Western, Cengage Learning.

Yen, Irene H., and S. Leonard Syme. 1999. The Social Environment and Health: a Discussion of the Epidemiologic Literature. Annual Review of Public Health 20:287-308. http://dx.doi.org/10.1146/annurev.publhealth.20.1.287

DOI: http://dx.doi.org/10.6000/1929-4409.2016.05.04

(C) 2016 Nicholson et al.; Licensee Lifescience Global.

This is an open access article licensed under the terms of the Creative Commons Attribution Non-Commercial License (http://creativecommons.org/licenses/by-nc/3.0/) which permits unrestricted, non-commercial use, distribution and reproduction in any medium, provided the work is properly cited. 